\title{
KASUS HOAKS PANDEMI COVID-19: SUATU TINJAUAN LINGUISTIK FORENSIK
}

\author{
Nur Handayani, Johar Amir, dan Juanda \\ Program Pascasarjana Magister Pendidikan Bahasa, Universitas Negeri Makassar, \\ Makassar, Sulawesi Selatan Indonesia \\ nurhandayani191620@gmail.com
}

\begin{abstract}
ABSTRAK: Penelitian ini berfokus pada kajian linguistik forensik yang membahas mengenai Kasus Hoaks Pandemi Covid-19 yang beredar di media sosial. Adapun tujuan penelitian ini mendeskripsikan kategori kasus hoaks Covid-19 dan menganalisis karakteristik kebahasaan pada kasus kejahatan berbahasa yakni kasus hoaks dimasa pandemi Covid-19. Data dalam penelitian ini didapatkan melalui laman resmi kementrian komunikasi dan informatika (kemenkominfo). Teknik pengumpulan data dilakukan dengan teknik dokumentasi, teknik baca, teknik catat. Proses analisis data dalam mendeskripsikan kategori hoaks pandemi Covid-19 dengan mengidentifikasi data berdasarkan pemahaman teori kasus hoaks dan memahami hukum sesuai peraturan perundang-undangan. Sedangkan dalam proses menganalisis karakteristik kebahasaan pada kasus hoaks pandemi Covid-19 dengan menggunakan pendekatan semantik, sintaksis dan teori konteks Halliday. Hasil dalam penelitian ini terdapat dua bentuk kategori kasus hoaks mengenai pandemi Covid-19 yang banyak beredar di sosial media, yakni kasus hoaks berjenis misinformasi dan kasus hoaks berjenis disinformasi. Hasil analisis karakteristik kebahasaan yang menjadi penanda kebohongan berupa 1) penggunaan kosa-kata atau diksi 2) bentuk kalimat pada teks kasus hoaks 3) analisis konteks berisi fakta serta tujuan pelaku.

KATA KUNCI: Covid-19; hoaks; linguistik forensik.
\end{abstract}

\section{THE CASE OF THE COVID-19 PANDEMIC HOAX: AN OVERVIEW OF FORENSIC LINGUISTICS}

\begin{abstract}
This research focused on forensic Linguistic Review which discussed about hoax case of Covid-19 pandemic circulated in social media. The purpose of this research is to describe the category of Covid-19 hoaxes and to analyze the linguistics' characteristic of language wickedness' case which is hoax case of Covid-19 pandemic. The date in this research was gained by the official website of the Ministry of Communications and Informatics. The techniques of data collection were documentation technique, reading technique, and notepad technique. The process of data analysis to describe the category of Covid19 hoaxes were data identification based on theoretical comprehension of hoax cases and legislationbased-law comprehension. Meanwhile, in processes of linguistics' characteristic analysis on the hoax case of Covid-19 pandemic were semantics approach, syntax and Halliday context theory. The result of this research found that there are two categories on hoax case of Covid-19 pandemic which were circulating in social media, namely hoax cases caused by misinformation and hoax cases caused by disinformation. The linguistics' characteristic that became the sign of lies are 1) the using of vocabulary and diction; 2) the sentence structure in the hoax case text; 3) the context analysis which includes the fact and the goals of the perpetrators.
\end{abstract}

KEYWORDS: Covid-19; forensic linguistics, hoax.

\begin{tabular}{lccc}
\hline Diterima: & Direvisi: & Distujui: & Dipublikasi: \\
2021-07-05 & 2021-07-08 & 2021-09-01 & 2021-10-29 \\
& & & \\
Pustaka & Handayani, N., Amir, J., \& Juanda, J. (2021). KASUS HOAKS PANDEMI COVID-19: \\
& SUATU TINJAUAN LINGUISTIK FORENSIK. Fon: Jurnal Pendidikan Bahasa dan Sastra \\
Indonesia, 17(2), 169-177. doi:https://doi.org/10.25134/fon.v17i2.4432 \\
\hline
\end{tabular}

\section{PENDAHULUAN}

Tragedi Covid-19 yang telah melanda dunia termasuk negara Indonesia telah menyebabkan kekhawatiran di tengah-tengah masyarakat. Kekhawatiran disebabkan banyaknya kesimpangsiuran informasi yang telah beredar di media sosial, 
Kebenaran tersebut belum dinyatakan valid dan butuh validasi lebih lanjut. Kemudahan serta efisien dalam penggunaan berbagai media sosial menjadikan informasi mudah tersebar. Fenomena ini dapat memicu masyarakat terprovokasi dan menimbulkan rasa takut yang berlebihan hingga berdampak pada lingkungan sosialnya, serta kini informasi yang dianggap benar tidak mudah lagi ditemukan.

Masyarakat ketika melakukan aktivitasnya pada saat pandemi Covid19 melanda, lebih sering berinteraksi melalui berbagai media sosial, sehingga Jumlah pengguna akun di berbagai media internet meningkat sekitar $40 \%$ di masa-masa pandemi kali ini. Hal ini disebabkan anjuran yang dilontarkan oleh pemerintah pusat untuk melakukan segala kegiatan di rumah, dan menyebabkan aktifitas masyarakat cenderung lebih terfokus bekerja, mencari informasi, hiburan dan lainnya melalui jejaring sosial internet. Faktor untuk berada tetap di rumahpun menjadi pemicu masyarakat menyampaikan pernyataan-pernyataannya melalui media sosial. Melihat fenomena saat terjadinya pandemi Covid-19, permasalahan yang terjadi informasi Hoaks beredar dimanamana terlebih pada status-status di platfrom media sosial. Hal ini sebuah fenomena di era digitalisasi, sehingga tepat untuk menganalisis fenomena tersebut dengan menggunakan kajian ilmu linguistik forensik. Dengan berbagai bantuan ilmu linguistik forensik, seorang tenaga ahli dalam ilmu kebahasaan dapat memberikan bantuan kepada pihak kepolisian ketika melakukan sebuah proses penyelidikan. Kajian ilmu ini memiliki angka tingkat akurasi yang tinggi ketika mendeteksi suatu informasi yang melakukan kebohongan dalam mengungkapkan kasus-kasus kebahasaan seperti kasus hoaks (Hardaker, 2015).
Pihak Kepolisian Republik Indonesia memberikan informasi kepada masyarakat agar tidak menyebarkan kabar bohong (Hoaks) di berbagai media sosial. Polri akan bertindak tegas kepada penyebar sebuah informasi Hoaks di jejaring internet pada akun-akun yang tidak bertanggung jawab dengan pasal 28 ayat 1 Undang-Undang Informasi dan Transaksi Elektronik (UU ITE). Pasal 28 ayat 1 berupa: "(1) Setiap orang dengan sengaja dan tanpa hak menyebarkan berita bohong dan menyesatkan yang mengakibatkan kerugian konsumen dalam transaksi Elektronik". Sesuai ketentuan yang tertera dalam pasal tersebut, pada ayat 1 telah mengatur larangan untuk setiap orang menyebarkan sebuah berita bohong.

Penelitian ini berguna untuk meningkatkan kesadaran masyarakat. Memberikan edukasi dan membantu masyarakat agar memahami pernyataan hoaks yang dapat meresahkan dan merugikan masyarakat lainnya. Dilakukan dengan mencari tahu kebenaran suatu pernyataan pada sumber-sumber yang valid sebelum menyebar luaskan berita tersebut. Masyarakat perlu memahami bahwa siapapun yang menyebarkan berita hoaks dan menimbulkan kerugian kepada pihak lain dapat berdampak hukum dengan melanggar undang-undang ITE berupa penyebaran sebuah berita bohong.

Kasus mengenai hoaks melalui media internet telah menjadi sebuah fenomena baru di tengah masyarakat pada saat pandemi Covid-19 melanda. Fenomena ini menunjukkan masih banyak kalangan masyarakat kita yang belum memahami aturan hukum terkait dengan aktivitas-aktivitas di dunia maya. Berdasarkan fenomena yang terjadi, dibutuhkan suatu ilmu teoritis yang dapat menghubungkan antara permasalahan hukum yang terjadi dan pemahaman dari sebuah ilmu kebahasaan. Kehadiran 
linguistik forensik yang merupakan salah satu cabang dalam ilmu linguistik diharapkan menjadi sebuah wadah untuk dapat memecahkan permasalahan yang terjadi. Berdasarkan pemaparan tersebut, penelitian ini berjudul Kasus Hoaks Pandemi Covid-19: Suatu Tinjauan Linguistik Forensik.

\section{LANDASAN TEORI}

Dalam Penelitian ini akan digunakan sejumlah teori yang melandasi penelitian ini yaitu: 1. Berita Bohong (Hoaks) 2. Linguistik Forensik 3. Pendekatan Semantik 4. Pendekatan Sintaksis 5. Teori Konteks Halliday.

\section{Berita Bohong/palsu (Hoaks)}

Penggunaan kata hoaks untuk persamaan persepsi merujuk pada Kamus Besar Bahasa Indonesia/KBBI, kata hoaks dalam KBBI dikategorikan sebagai ajektiva dan nomina. Kata hoaks termasuk dalam kelas kata ajektiva mengandung arti tidak benar; bohong, sedangkan jika penulisannya sebagai frasa, hoaks ini dapat menggunakan kata yang diterangkan dahulu, misalnya menjadi "berita hoaks". Hoaks bisa termasuk ke dalam kelas kata nomina dengan arti "berita bohong" (KBBI, 2016). Sedangkan menurut Mauludi (2018:22). Hoaks adalah suatu kata yang digunakan untuk menunjukkan pemberitaan palsu atau usaha untuk menipu atau mengakali pembaca atau pendengarnya untuk memercayai sesuatu yang biasanya digunakan dalam media sosial, misalnya: facebook, tweeter, whatsapp, blog, dll.

\section{Linguistik Forensik}

Linguistik Forensik didefenisikan sebagai penerapan ilmu linguistik dalam suatu ranah sosial khusus, yakni ranah hukum (Olsson, 2008). Teori linguistik forensik ini mengaplikasikan sebuah teori yang termasuk dalam teori linguistik dalam sebuah peristiwa kebahasaan yang termasuk dalam kejahatan berbahasa yang dapat berdampak hukum, baik dalam bentuk produk hukum, interaksi dalam sebuah proses peradilan, dan adanya interaksi antar perorangan yang mengakibatkan timbulnya sebuah proses hukum tertentu. Dalam hal ini, teori-teori linguistik yang diaplikasikan meliputi teori dalam struktur kalimat, sebuah percakapan, analisis sebuah wacana, linguistik kognitif, tindak tutur, teori dan teknik linguistik deskriptif, seperti pragmatik, semantik, fonologi, sintaksis dan lainnya (Coulthard dan Alison, 2010). Sehingga dapat disimpulkan Linguistik Forensik adalah cabang linguistik terapan yang mengaplikasikan teori-teori yang termasuk dalam ilmu linguistik terhadap suatu peristiwa kebahasaan yang terlibat dalam sebuah proses hukum atau berdampak hukum.

\section{Semantik}

Semantik merupakan cabang ilmu linguistik yang meneliti arti atau makna. kata bisa diberi definisi sebagai "a linguistik unit has a single meaning", satu kesatuan linguistik yang mempunyai makna tunggal. Jadi semantik dapat dibagi atas semantik leksikal dan semantik gramatikal (Verhaar, 2010:385). Adapun yang dimaksud makna leksikal adalah makna dari arti yang sebenarnya, terdapat makna pada leksem meski tanpa melihat konteks situasi yang terjadi. Sebuah makna yang nampak dari hasil observasi indra kita, atau makna yang apa adanya. Hal ini terdapat pada kamus-kamus dasar yang memuat sebuah makna leksikal yang dimiliki oleh kata yang dijelaskannya. Sedangkan makna gramatikal terjadi setelah proses gramatikal, seperti afiksasi, reduplikasi, komposisi (Chaer,1994: 289-290).

\section{Sintaksis}

Sintaksis mempelajari susunan kata-kata dalam suatu rangkaian yang bermakna atau yang disebut dengan kalimat (Khatimah, 2016:12). Fungsi 
kalimat dalam hubungan situasi dapat digolongkan menjadi tiga golongan yakni, a. Kalimat imperatif (kalimat perintah/suruh), mengharapkan tanggapan berupa sebuah tindakan terhadap lawan bicara, pola dari intonasi kalimat suruh ditandai dengan tanda seru /!/. Berdasarkan strukturnya kalimat suruh dapat digolongkan menjadi empat golongan, kalimat suruh yang sebenarnya, kalimat persilahan, kalimat ajakan, dan kalimat larangan. b. Kalimat deklaratif (kalimat pernyataan/berita), kalimat berita memiliki fungsi untuk memberikan informasi kepada orang lain. Tanggapan yang diharapkan dari lawan tutur berupa perhatian seperti tergambarkan pada pandangan mata yang menggambarkan adanya sebuah perhatian. Terkadang perhatian itu disertai sebuah anggukan kepala atau disertai ucapan $y a$. Kalimat berita memiliki pola intonasi yang disebut pola intonasi berita. c. Kalimat Intogratif (kalimat tanya), berfungsi untuk menanyakan perihal sesuatu. Pola intonasi dan nada sebuah kalimat tanya bernada akhir naik, dan pola intonasi digambarkan dengan tanda tanya. Salah satu tanda kalimat tanya adalah penggunaan kata $5 \mathrm{~W}+1 \mathrm{H}$ (Ramlan. 2005: 26-43).

\section{Teori Konteks Halliday}

Menganalisis sebuah kasus kejahatan berbahasa tentunya perlu memahami hubungan konteks dalam situasi yang terjadi dan kondisi dari sebuah peristiwa. Setelah diketahui konsep berfikir verbal dan non verbal, kronologi maupun keterangan saksi-saksi juga diperlukan dalam menganalisis sebuah teks yang sedang disengketakan (Sholihatin, 2019:109-110). Dengan demikian dapat diketahui fakta serta tujuan dari teks tersebut diproduksi.

Konteks menurut Malinowski meliputi konteks situasi dan konteks budaya yang selanjutnya dikembangkan oleh Halliday dan Hasan. Untuk melihat konteks pada teks kasus hoaks/berita bohong digunakan pendekatan konteks menurut Halliday karena pendekatan tersebut komprehensif dan aplikatif. Menurut Halliday (1992:16), ada tiga faktor konteks situasi yang memengaruhi pilihan bahasa seseorang, yaitu medan (field), pelibat (tenor), dan sarana (mode) seperti pada tabel berikut.

\begin{tabular}{|c|l|l|}
\hline \multicolumn{2}{|l|}{ Konteks Situasi } \\
\hline Medan (field) & Pelibat (tenor) & $\begin{array}{l}\text { Sarana } \\
\text { (mode) }\end{array}$ \\
\hline- & $\begin{array}{l}\text { Partisipan } \\
\text { - Status/peran } \\
\text { - Hubungan } \\
\text { pelibat }\end{array}$ & $\begin{array}{l}\text { Tipe interaksi } \\
\text { Medium/saluran } \\
\text { Modus retoris }\end{array}$ \\
\hline
\end{tabular}

Medan wacana (field) mengacu pada peristiwa yang terjadi atau topik yang dibicarakan dan dalam hal ini bahasa merupakan komponen yang esensial, berupa pesan apa yang hendak disampaikan melalui proses sosial. Pelibat wacana (tenor) mengacu pada partisipan, status dan perannya, kepada siapa pesan itu hendak disampaikan. Sarana (mode) mengacu pada bagian yang diperankan bahasa (fungsi khas bahasa) dalam format bahasa yang bagaimanakah pesan itu disampaikan (Mahsun, 2018:48).

\section{METODE}

Jenis penelitian berupa penilitian kualitatif deskriptif, yakni digunakan mendeskripsikan kategori kasus hoaks Covid-19 dan menganalisis karakteristik kebahasaan pada kasus kejahatan berbahasa yakni kasus hoaks dimasa pandemi Covid-19 secara alamiah. Penelitian ini menggunakan desain penelitian analisis isi/konten. Dengan demikian penelitian linguistik forensik ini upaya penyelidikan suatu permasalahan hukum dengan menggunakan data bahasa sekaligus teknik-teknik ilmu kebahasaan secara sistematis dan objektif.

Adapun data bahasa dari penelitian ini adalah teks kasus berita hoaks atau 
berita bohong dimasa pandemi covid-19. Sumber data dalam penelitian ini, diperoleh dari laman resmi Kementrian Komunikasi dan Informatika (Kemenkominfo) Republik Indonesia yang sudah termasuk pelanggaran hukum sesuai dengan aturan perundangundangan yang berlaku. Teknik pengumpulan data yang digunakan teknik dokumentasi, teknik baca, dan teknik catat. Proses menganalisis data-data tersebut kemudian dianalisis berdasarkan aspek-aspek linguistik yang digunakan dalam linguistik forensik seperti teori semantik leksikal dan gramatikal, teori sintaksis dan analisis teori konteks Halliday.

\section{HASIL DAN PEMBAHASAN}

Menganalisis sebuah data dalam penelitian ini dengan kajian linguistik forensik, tentu memperhatikan dua hal yang harus dipahami berupa menganalisis menggunakan ilmu linguistik dalam teks kasus hoaks di masa pandemi Covid-19 dan mengkategorikan kasus hoaks untuk menentukan ada tidaknya unsur kriminal. Penyajian penelitian ini, menggabungkan pemahaman kategori kasus hoaks di masa pandemi Covid-19 dan pemahaman secara linguistik agar memperoleh hasil penyajian yang memadai. Berdasarkan hal tersebut, maka deskripsi kategori kasus hoaks Covid-19 dan karakteristik kebahasaan pada kasus kejahatan berbahasa yakni kasus hoaks dimasa pandemi Covid-19, dapat dijabarkan sebagai berikut:

\section{Kasus Hoaks Pandemi Covid-19 Berjenis Misinformasi}

Misinformasi adalah informasi palsu/bohong yang dibuat tanpa maksud untuk menyesatkan, informasi yang memang tidak benar atau tidak akurat, namun pihak terkait tidak paham bahwa informasi yang disebarkannya adalah berita bohong.

\section{Ibu Rumah Tangga Penyebar Hoaks Virus Corona di Lampung}

Terdapat sebuah postingan di jejaring sosial yakni sosial media Facebook, diunggah oleh seorang ibu rumah tangga (IRT) di Tanggamus Lampung pada tanggal 3-4 Maret 2020. Ditangkap aparat Kejahatan Siber Polda Lampung karena menyebarkan hoaks virus corona, tersangka berinisial OER (28) diamankan setelah Tim Subdit V Kejahatan Siber Ditkrimsus menyelidiki sebuah postingan yang meresahkan terkait virus corona.

Pada unggahan pertama, 3 Maret 2020.

Awas di Kabupaten Pringsewu ada yang

kena Corona, baru pulang dari Malaysia.

Pada unggahan kedua, 4 Maret 2020.

Hati hati virus corona sudah di

Lampung.

Data yang terdapat dalam kasus hoaks di atas merupakan bentuk data hoaks berjenis misinformasi yaitu informasi yang dibuat tanpa maksud untuk menyesatkan namun terdapat kelalaian yang diperbuat oleh tersangka dengan tidak mencari kebenaran terlebih dahulu dari sebuah informasi yang diperoleh. Terdapat sebuah diksi yang digunakan dapat dimaknai menggunkan semantik leksikal yakni memelajari makna kata secara lepas tanpa mengaitkan kedudukan kata dengan kalimat. Pada unggahan pertama terdapat kata verba "Awas", dalam kamus besar bahasa indonesia bermakna leksikal: dapat melihat baik-baik; memperhatikan dengan baik; tajam tiliknya. Kata verba "Ada" bermakna hadir; telah sedia. Sedangkan verba "Kena" berarti bersentuhan; tepat pada sasaran. Kata tersebut merujuk kepada diksi "Corona" sebuah virus menular yang menyerang sistem pernapasan. Secara gramatikal dimaknai dengan jelas 
bahwa pelaku OER sedang memberikan peringatan kepada pembaca postingannya bahwa terdapat masyarakat Pringsewu yang terkena virus Corona, warga tersebut baru pulang dari negeri tetangga Malaysia.

Pada hari berbeda OER kembali mengunggah status kedua, kata adverbia "Hati-hati" bermakna ingat-ingat; waspada. "Virus corona" sebuah virus menular yang menyerang sistem pernapasan berada di Lampung. Lampung adalah Provinsi di Pulau Sumatera. Dari analisis secara leksikal tersebut, sangat jelas jika tersangka berusaha memperingati dan memberikan informasi kepada masyarakat sekitar atau pengikutnya di sosial media, berupa telah terdapat korban virus corona di daerahnya yakni Lampung sebuah Provinsi di Pulau Sumatera agar berhatihati.

Teks status hoaks diatas termasuk kategori kalimat imperatif/suruh berupa suruhan untuk waspada dan berhati-hati. Pada status unggahan 3 Maret 2020, suruhan agar tetap waspada dengan menggunakan kata "Awas", penggunaan diksi tersebut menimbulkan rasa kecemasan yang berlebih pada masyarakat. Begitupun dengan status unggahan 4 maret OER menggunakan diksi "Hati-hati" menyeru pembaca untuk berhati-hati sehingga dampak pada masyarakat menimbulkan rasa kecemasan dan ketakutan, masyarakat berada di rumah dengan situasi takut beraktivitas karena dirundung kecemasan serta menimbulkan stres berlebih kepada masyarakat.

Analisis dengan mengidentifikasi, (Medan/field): pesan yang hendak disampaikan ialah pesan bernuansa kejahatan berbahasa berupa kasus hoaks, berdasarkan fakta dikonfirmasi dari kepolisian bahwa pada tgl 3 maret 2020 tidak ada data mengenai kasus positif corona di Kabupaten Pringsewu.
(Pelibat/tenor): tersangka hendak menginformasikan kepada masyarakat Lampung. (Sarana/mode): Informasi ini disebarkan melalui media online facebook dengan ragam bahasa santai. Secara konteks, alasan mengapa status ini diperkarakan karena kedua unggahan tersebut dibaca hingga lebih dari 4.000 warganet. Dampak dari unggahan tersangka ini meresahkan warganet di Lampung.

Pada bulan maret, status diuggah pertama-kali oleh pelaku merupakan awal virus corona tersebar di Indonesia, pada saat itu masyarakat mudah ketakutan karena minim pengetahuan terhadap jenis virus baru tersebut. Masyarakat mempercayai pelaku karena pelaku merupakan calon TKW yang gagal berangkat akibat dampak dari berita yang tersebar mengenai virus corona. OER mengaku menulis status itu lantaran merasa panik dan ketakutan mendapat informasi tersebut saat dia mendaftar menjadi TKW pemberangkatan Malaysia, untuk melampiaskan rasa stresnya pelaku meluapkannya di sosial media berupa status facebook. Dari pihak kepolisian kasus ini terkena Pasal $45 \mathrm{a}$ ayat $2 \mathrm{UU}$ No. 19 tentang perubahan undangundang no 11 tentang ITE. "Ancaman 6 tahun penjara atau denda Rp 1 miliar,", status perkara sementara diproses.

\section{Kasus Hoaks Pandemi Covid-19 Berjenis Disinformasi}

Disinformasi adalah informasi palsu/bohong yang dibuat dengan maksud menyesatkan dan menipu pembaca, informasi yang tidak benar namun memang direkayasa (fabricated) sedemikian rupa oleh pihak-pihak yang ingin membohongi masyarakat, hal ini dilakukan karena unsur kesengajaan agar mudah mempengaruhi opini publik dan mendapatkan sebuah keuntungan pribadi dari informasi yang disebarkannya. 


\section{Asap Batok Kelapa Merupakan Obat Covid-19}

Postingan ini beredar di media sosial Facebook, video memiliki durasi 2 menit 47 detik yang mengklaim asap batok kelapa yang sudah dikondensasi bisa menyembuhkan pasien yang terjangkit virus Covid-19. Unggahan ini kemudian disebarkan dan diteruskan oleh pengguna akun facebook lainnya hingga menggegerkan masyarakat.

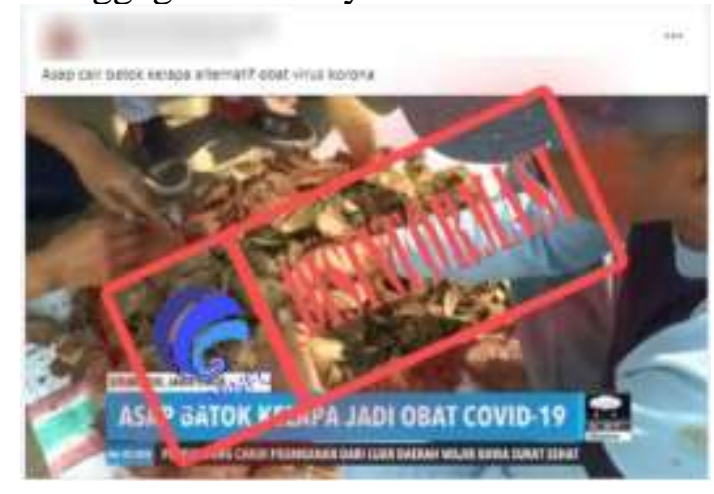

Teks: Asap cair batok kelapa alternatif obat virus corona (unggahan disertai video).

Kasus tersebut berjenis disinformasi, berita yang disebarkan dengan maksud menyesatkan pembaca, informasi yang terdapat pada konten tersebut hanya sekedar pendapat tanpa bukti ilmiah dan disinyalir alasan ini digunakan seseorang untuk memperoleh keuntungan pribadi. Berdasarkan pemaknaan leksikal kata nomina "Asap" berarti uap yang dapat terlihat dihasilkan dari pembakaran, sedangkan kata nomina "Batok" yang berarti tempurung, merujuk kepada kata nomina buah "kelapa" tumbuhan palem yang tertutup sabut dan tempurung yang keras, sehingga "Batok kelapa" mengandung makna tempurung yang menutupi kelapa. Pemilihan diksi lainnya kata nomina "Alternatif" bermakna leksikal, pilihan diantara dua atau beberapa kemungkinan. Sedangkan "Obat" berarti bahan untuk mengurangi, menghilangkan penyakit, atau menyembuhkan seseorang dari penyakit. Diksi tersebut merujuk kepada "Virus corona" sebuah penyakit menular yang menyerang sistem pernapasan. Berdasarkan analisis kata pada unggahan dapat dimaknai secara gramatikal bahwa asap yang dihasilkan dari proses pembakaran tempurung kelapa menjadi sebuah temuan dalam penyembuhan penyakit virus Corona.

Kalimat Asap cair batok kelapa alternatif obat virus corona termasuk jenis kalimat pernyataan atau berita, kalimat yang bersifat membutuhkan perhatian dari khalayak. Unggahan tersebut berniat memberitahukan kepada masyarakat bahwa telah ditemukan obat yang dapat menyembuhkan Covid-19, berupa asap dari pembakaran tempurung kelapa. Informasi ini dapat menyesatkan karena menyebarkan berita tanpa adanya dasar ilmiah dan tidak melalui uji coba laboratorium, berita ini terbukti mendapatkan perhatian lebih dari masyarakat karena banyaknya yang menyebarkan kembali unggahan tersebut.

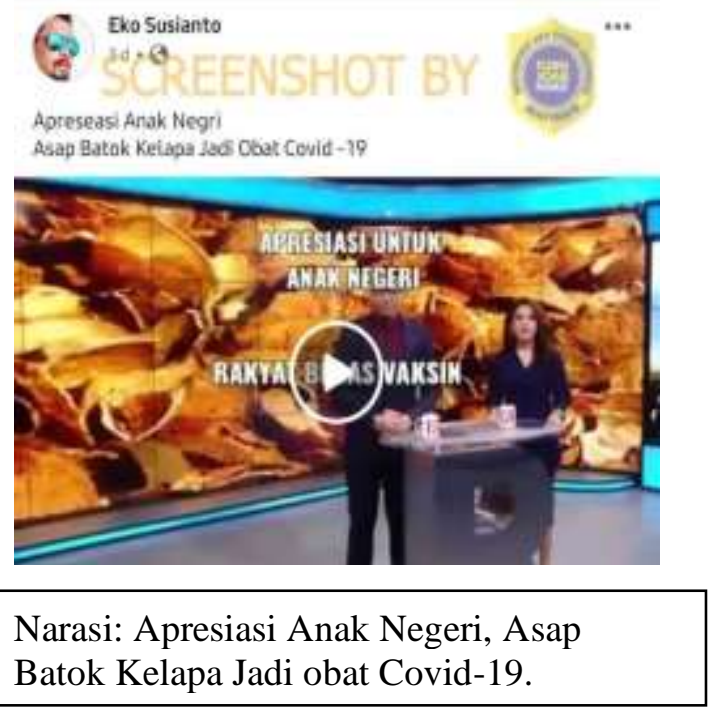

Berita yang sama kembali di unggah oleh (ES) pengguna akun media sosial facebook, mengunggah status berupa kata nomina "Apresiasi" mengandung makna leksikal kesadaran terhadap nilai; penilaian (penghargaan) terhadap sesuatu. Sedangkan "Anak negeri" mengandung arti warga pribumi 
atau warga asli Indonesia. Jadi makna gramatikal dari kalimat tersebut adalah penghargaan yang telah diberikan kepada warga asli Indonesia atas pencapaiannya berhasil menemukan obat dari Covid-19. Kalimat pernyataan/berita tersebut dikatakan berita bohong karena informasi yang beredar tidak memiliki dasar ilmiah sehingga informasi tersebut berisi konten yang menyesatkan

Analisis berdasarkan konteks, (Medan/field): Informasi bohong/hoaks yang menyesatkan mengenai penemuan obat covid-19 berupa asap dari pembakaran batok kelapa. Klaim ini dikatakan hoaks karena sampai saat ini, belum ditemukan sebuah obat khusus yang dapat mencegah atau mengobati penyakit yang disebabkan virus corona (Covid-19). Obat-obat herbal yang beredar di masyarakat hanya obat-obatan yang dapat digunakan untuk meredakan, bukan obat yang dapat menyembuhkan. Masyarakat yang positif virus corona harus menjalani perawatan yang tepat untuk meredakan hingga mengobati gejala tentu dengan meningkatkan daya tahan tubuh dan mereka yang mengalami gejala serius harus dibawa ke rumah sakit. Hal ini pun didukung oleh pendapat ahli, yaitu Dr. Samuel P. K. Sembiring menyatakan video yang tersebar merupakan informasi bohong, hal yang dapat dilakukan terhadap Covid-19 adalah mencegahnya dengan menerapkan protokol kesehatan karena sampai saat ini belum ada penemuan obat Covid-19. (Pelibat/tenor): informasi ditujukan kepada seluruh masyarakat, unggahan tersebut menjadi konsumsi obrolan ditengah warga net ketika berita tersebut disiarkan oleh stasion televisi, sehingga berita ini tidak hanya tersebar diwilayah pulau Jawa saja melainkan seluruh Indonesia. (Sarana/mode): status tersebut menggunakan ragam bahasa santai yang diunggah di media sosial facebook. Warga Net yang ikut menyebarkan informasi tersebut tidak melakukan proses penyaringan lebih dalam, alasan memposting karena turut bahagia dan mengapresiasi temuan ini, Covid-19 bisa disembuhkan dengan obat herbal, namun konten ini dapat merugikan masyarakat.

\section{KESIMPULAN}

Berdasarkan analisis yang telah dilakukan dalam penelitian ini terdapat dua bentuk kategori kasus hoaks mengenai pandemi Covid-19 yang banyak beredar di sosial media, yakni kasus hoaks berjenis misinformasi dan kasus hoaks berjenis disinformasi. Adapun dasar hukum untuk pengkategorian kasus hoaks di atas dan yang dapat menjerat para pelaku penyebar kategori kasus hoaks tersebut berdasarkan Undang-undang Republik Indonesia Nomor 1 Tahun 1945 tentang peraturan hukum pidana, berita bohong (hoaks) diatur dalanm pasal 14 dan 15, dan Undang-Undang Nomor 11 Tahun 2008 tentang Informasi dan Transaksi Elektronik pasal 27. Selain itu dalam penelitian ini ditemukan beberapa analisis fitur linguistik yang menjadi penanda kebohongan berupa 1) penggunaan kosa-kata atau diksi menggunakan ragam bahasa santai yang bersifat verba, nomina dan adjektiva. 2) Bentuk kalimat pada teks kasus hoaks mengenai pandemi Covid-19 banyak menggunakan kalimat deklaratif (pernyataan), lalu imperatif (perintah) dan interogatif (pernyataan), tentu pemilihan bentuk kalimat ini menunjukkan jejak ideologis penulisnya. 3) Menganalisis berdasarkan konteks, seorang kosumen teks akan terpacu untuk terus mengonfirmasi kebenaran isi teks yang dibacanya.

\section{DAFTAR PUSTAKA}

Chaer, Abdul. 1994. Linguistik Umum. Jakarta: Rineka Cipta.

Coulthard, M. and Johnson, A. 2007. An Introduction to Forensic 
Sastra Indonesia

FKIP Universitas Kuningan

\begin{tabular}{l|ll} 
Linguistics: Language in & Strategi dan & Diplomasi \\
Evedence. London: Routledge. & Kebahasaan.
\end{tabular} Hardaker. 2015. The ethics of online aggression: Where does virtual end, and reality begin?. International Journal of Speech, Language, and The Law. Vol. 11,261-266.

Halliday, M.A.K dan Ruqaiya Hasan. 1992. Bahasa, Konteks dan Teks. Yogyakarta: Gajah Mada University Press.

KBBI, 2016. Kamus Besar Bahasa Indonesia (KBBI). [Online] https://kbbi.kemdikbud.go.id/entr i/hoaks. Diakses 15 Desember 2020.

Khatimah, khusnul. 2016. Pedoman Kajian Linguistik Forensik Forensics Linguistics Research Guidebook. Bandung. Disahkan oleh Kepala Pusat Pengembangan
Mahsun. 2018. Linguistik Forensik Memahami Forensik Berbasis Teks dengan Analogi DNA. Depok: Rajawali Pers.

Mauludi, Sahrul. 2018. Seri Cerdas Hukum Awas Hoax!. Jakarta: PT. Elex Media Komputindo.

Olsson, john. 2008. Forensic Linguistics, Second Edition. London: Continuum.

Ramlan,M. 2005. Ilmu Bahasa Indonesia Sintaksis. Yogyakarta: CV. Karyono.

Sholihatin, Endang. 2019. Linguistik Forensik dan Kejahatan Berbahasa. Yogyakarta: Pustaka Pelajar.

Verhaar, J.W.M. 2010. Asas-Asas Linguistik Umum. Yogyakarta: Gadjah Mada Press. 